\title{
Filozofija kao humanistička znanost ${ }^{1}$
}

Filip Grgić*

filip@ifzg.hr
UDK: 1:009

Izlaganje sa znanstvenog skupa / Conference paper

Primljeno: 31. ožujka 2016.

Prihvaćeno: 15. travnja 2016.

U članku se raspravlja o tome kako smjestiti filozofiju u odnosu na druga polja humanističkih znanosti. Tvrdi se da ne postoji nešto takvo kao što je neovisno ili čisto filozofsko istraživanje: filozofska je aktivnost uvijek prožeta uvidima, rezultatima i metodama koje su specifične za prirodne, društvene i humanističke znanosti. Filozofija je nužno samo dio kolektivnog pothvata razumijevanja svijeta, koji obuhvaća različite discipline. Kao posljedica toga, ne postoji neki poseban problem odnosa između filozofije i znanosti, uključujući i humanističke znanosti.

Ključne riječi: filozofija, humanističke znanosti, nesigurnost, znanost.

Pitanja o tome u kojem je smislu filozofija humanistička znanost, zašto je važna činjenica da ona pripada upravo području humanističkih znanosti, a ne nekih drugih, što za filozofiju znači to što je dio humanističkih znanosti i slična pitanja - mi filozofi smatramo osobito važnima. Zašto ih smatramo važnima? Zašto je za nas činjenica da je filozofija dio humanističkih znanosti važnija nego što je, pretpostavljam, matematičaru važna činjenica da je matematika dio prirodnih znanosti ili ekonomistu činjenica da je ekonomija dio društvenih znanosti? Mislim da stvar nije u tome što bismo mi možda smatrali da postoji nešto naročito prijeporno $u$ činjenici da je filozofija humanistička znanost. $\mathrm{Ne}$ smatram da u tome ima ičega prijepornog. Točnije, pretpostavljam da većina filozofa, barem većina filozofa u Hrvatskoj, tu činjenicu ne smatra spornom. (Možda su spornije činjenice da je, prema trenutno važećoj klasifikaciji znanostî u Hrvatskoj, teologija humanistička znanost, matematika prirodna znanost, a

\footnotetext{
${ }^{1}$ Izlaganje na znanstvenom skupu Instituta za filozofiju s temom: »Smisao humanističkih znanosti«, a održanom u Palači Matice hrvatske u Zagrebu, 10. prosinca 2015. Cjelovit će rad biti objavljen u zborniku skupa.

* Prof. dr. sc. Filip Grgić, znanstveni savjetnik, Institut za filozofiju, Ulica Grada Vukovara 54, HR-10000 Zagreb.
} 
kineziologija društvena znanost. No ne smijemo zaboraviti na to da je podjela znanosti na područja kontingentna činjenica, koja ovisi ne samo o povijesnom nasljeđu nego je, kod nas, propisana nečim što se zove »Pravilnik o znanstvenim i umjetničkim područjima, poljima i granama«, dokumentom što ga donosi Nacionalno vijeće za znanost, visoko obrazovanje i tehnološki razvoj, a koji je stvar znanstvene politike i podložan promjenama.) Isto tako, ne smatram da o statusu filozofije kao humanističke znanosti mi filozofi više razmišljamo samo zato što smo osobito zainteresirani za metafilozofska pitanja o statusu filozofije kao discipline (i kao što, ako razmišljamo o metamatematičkom pitanju o tome zašto bi matematika bila upravo prirodna znanost, onda smo zapravo filozofi matematike više nego matematičari). Mi jesmo zainteresirani za metafilozofska pitanja više nego drugi i pitanje što za filozofiju znači biti dio korpusa humanističkih znanosti jest metafilozofsko pitanje koje je prirodan predmet zanimanja filozofâ. No mene ovdje zanima nešto drugo.

Ono što želim tvrditi otprilike je sljedeće. Razlog zbog kojeg smo naročito, više nego drugi, zainteresirani za točno pozicioniranje naše discipline u odnosu na humanističke znanosti samo je poseban slučaj naše nesigurnosti koju možemo detektirati u odnosu prema znanostima općenito. Ili, točnije, različitost stilova i senzibiliteta koje nalazimo u današnjoj filozofiji može se shvatiti kao nešto što stoji, u najmanju ruku, u korelaciji s tom općenitom nesigurnošću. Kada tu nesigurnost osvijestimo i kada shvatimo u čemu se ona sastoji, tada će nam se, nadam se, problem pozicioniranja prikazati kao pseudoproblem.

Odnos filozofije prema znanosti općenito, osobito prema prirodnoj znanosti, notorni je problem. Čini se da se o toj temi zapravo ne može kazati više ništa informativno i novo te da se različita i ponekad suprotstavljena stajališta uglavnom svode na naše poznate sporove o primjerenoj metodi ili o samoj naravi filozofije, to jest na različite stilove i senzibilitete koje možemo naći u današnjoj filozofiji. Uz to, trebamo imati na umu da na pitanje o odnosu filozofije i znanosti možda i ne možemo dati definitivan odgovor jednostavno zato što se taj odnos tijekom stoljećâ toliko mijenjao da nam se koji put može činiti da je apsolutno svaki odgovor moguć. S druge strane, sada, na početku 21. stoljeća, u nekoj smo mjeri u boljem položaju nego prije, jednostavno zato što je iscrpljeno više mogućnosti, a razina suptilnosti i znanosti i filozofije dosegla je onaj stupanj na kojemu možda možemo ponuditi obuhvatniji odgovor nego prije. (Ili je možda upravo zbog tih razloga odgovor teže pronaći.)

Kako bih karakterizirao taj odnos maločas sam, kao preliminarni opis, upotrijebio riječ »nesigurnost«. Uzmimo taj opis u sasvim jednostavnom smislu: nismo sigurni u to koji točno odnos filozofija treba zauzeti prema znanosti (pritom mislim na prirodnu znanost), po čemu se filozofski pristup svijetu razlikuje od znanstvenoga, što za filozofiju znače norme znanstvene metode itd. Manifestacije takve vrste nesigurnosti mogu biti raznolike. Jedan odgovor, primjerice, može biti oponašanje znanosti, koje nam je poznato u raznim oblicima: 
od ustrojavanja filozofskih radova po uzoru na članke u prirodoznanstvenim časopisima, nepotrebnog formaliziranja i kvaziformaliziranja tamo gdje za to ne postoji jasna potreba, pa do takva shvaćanja filozofije prema kojemu njezine premise mogu biti samo znanstvene teorije i hipoteze - a ne, primjerice, takozvane intuicije, značenja riječi, povijesni uvidi itd. - koje se onda oprezno generaliziraju, uspoređuju s drugim teorijama i hipotezama i slično. Ovdje ne mogu ulaziti u pitanje o tome kako i zašto je do toga došlo, je li bilo nužno da to toga dođe i koja je vrijednost toga. Stalo mi je samo do toga da, pomalo dogmatski, to opišem kao današnju manifestaciju svojevrsne nesigurnosti.

No ta se nesigurnost može manifestirati i na drukčiji način. Naime, na drugom ekstremu ona se često manifestira kao neka vrsta oholosti. Bahat stav što ga često zauzimamo prema znanosti obično se svodi na tvrdnju, prvo, da je filozofija nešto sasvim različito od znanosti, da je ona disciplina u kojoj se postavljaju sasvim različita pitanja pa onda i nude sasvim drukčiji odgovori. Taj se stav onda ponekad svodi i na zamisao da je filozofija ne samo drukčija od znanosti nego i iznad nje, da prodire u dubinu i širinu u koje znanost ne može prodrijeti - da ona navodno nudi takozvanu dublju ili širu sliku zbilje, tako da znanstvenici zapravo i ne znaju što rade sve dok im filozofi ne kažu što je to (a zanimljivo je da filozofi koji zagovaraju ovakav stav prema znanosti najčešće o njoj ne znaju puno).

Ne znam koliko je ovaj jeftini psihologistički opis - kombinacija nesigurnosti i oholosti - utemeljen i može li se na njemu graditi ikakav zanimljiv i relevantan opis odnosa filozofije i znanosti. Ne mogu, primjerice, tvrditi da je nesigurnost prema statusu filozofije u odnosu na znanosti nešto iz čega sigurno proizlaze razni stilovi filozofije koje sam spomenuo. Nesigurnost je samo opis stanja, a ne opis podrijetla, a za različitost stilova i senzibiliteta ne mogu tvrditi ništa više nego da je u korelaciji s njom. Odgovor na pitanje zašto filozofija danas izgleda tako kako izgleda sigurno je puno složeniji. No mislim da opis koji se temelji na pojmovima nesigurnosti i oholosti može biti koristan kao nekakvo najopćenitije polazište. Što je važnije, može biti koristan kao polazište prilikom razmišljanja o odnosu između filozofije i ostalih humanističkih disciplina.

Kada razmišljamo o odnosu filozofije i znanosti, tada, što je zanimljivo, u znanosti obično ne uključujemo humanističke znanosti; obično mislimo samo na prirodne znanosti. Više je razloga tome. Jedan se sigurno tiče činjenice što smatramo da je, zbog nekog razloga, važnije filozofiju pozicionirati u odnosu na prirodne znanosti nego u odnosu na humanističke znanosti, kamo filozofija, barem po formalnoj akademskoj klasifikaciji, spada. Drugi se razlog tiče činjenice što smatramo, s pravom, da nije moguće ponuditi odgovor koji bi bio tako obuhvatan da bi mogao karakterizirati odnos filozofije prema tako različitim područjima znanosti kao što su prirodne i humanističke. (Kao što se može zaključiti, ovdje pretpostavljam da je sasvim primjereno o humanističkim znanostima govoriti kao o znanostima. U moje je svrhe posve irelevantno koje 
je točno značenje izraza »znanost«, »science« ili »Wissenschaft«.) No zapravo rijetko razmišljamo i o tome koji je odnos filozofije prema zasebnom području humanističkih znanosti. Na početku sam kazao da pitanje što za filozofiju znači biti dio korpusa humanističkih znanosti smatramo osobito važnim. Sada bih mogao dodati kvalifikaciju: to pitanje smatramo osobito važnim kada filozofiju, zajedno s ostalim humanističkim disciplinama, kontrastiramo s prirodnim znanostima - kada, primjerice, naglašavamo da filozofija kao humanistička disciplina ima drukčije metode ili drukčije kriterije prosudbe nego prirodne znanosti, ili pak kada naglašavamo, primjerice, da filozofija kao humanistička disciplina nudi drukčiji pogled na svijet itd. No manje razmišljamo o pitanju je li sve to stvarno tako i koji je zapravo odnos filozofije prema humanistici u cjelini, a ne prema njezinim pojedinim poljima.

Moj je odgovor na to pitanje isti kao i u prethodnom slučaju: nismo sigurni. Manifestacija te nesigurnosti donekle je paralelna nesigurnosti za koju mislim da sam je detektirao što se tiče odnosa filozofije prema znanosti u užem smislu riječi, naime prirodnoj znanosti. Na jednom ekstremu, ta se nesigurnost također ponekad očituje u svojevrsnom oponašanju, pri čemu je oponašanje o kojem je ovdje riječ kompleksnije nego u prethodnom slučaju. Ponekad se, primjerice, oponašaju trendovi karakteristični za druga humanistička polja - kao tipičan primjer na pamet pada ono što se u raznim oblicima pojavljuje pod zajedničkim nazivom postmodernizma. Ponekad se kao uzorna ili, blaže, filozofiji najsrodnija disciplina pretpostavlja neka od humanističkih disciplina - najčešće je to povijest - pa se i predmet i svrha i metoda filozofskog istraživanja shvaćaju po uzoru na nju, kao kad se, primjerice, tvrdi da se proučavanje filozofskih problema svodi na proučavanje povijesti filozofije. Ili se pak ponekad kao uzor ne uzima neka humanistička disciplina, nego njezin predmet, primjerice književnost, najčešći rezultat čega je filozofija u obliku (obično loše) književnosti ili pak, što predstavlja naročitu perverziju, u obliku verbalizma i opskurantizma lišenih sadržaja.

Sve se to, kao i u prethodnom slučaju prirodnih znanosti, može nazvati raznim stilovima filozofiranja ili različitim filozofskim senzibilitetima. (Iako ovdje često postaje prijeporno koliko te stilove i senzibilitete uopće možemo nazivati filozofskima.) To jesu stilovi i senzibiliteti; međutim, kada se postavi općenito pitanje: »Koji je odnos filozofije prema znanosti, a osobito prema humanističkim znanostima?«, ti stilovi i senzibiliteti upućuju na odgovor: »Nismo sigurni«. Mi kao filozofi nesigurni smo u pogledu toga gdje stojimo u odnosu na ostala područja intelektualne aktivnosti, i to, čini mi se, u puno više nego što su, ako uopće jesu, istraživači u drugim područjima nesigurni u pogledu statusa svoje discipline. Oni mogu očitovati manjak samopouzdanja u pogledu sadašnjeg stanja ili budućnosti svoje discipline, ali rijetko će, čini mi se, biti nesigurni u pogledu toga kamo njihova disciplina uopće spada. A kao i u prethodnom slučaju, ta nesigurnost onda lako prelazi u oholost, koja filozofiju prikazuje kao 
u nekom smislu nadmoćnu baš svim disciplinama, pa tako i humanističkima. Pojedine humanističke discipline tada prolaze upravo kao pojedine prirodne znanosti u prethodnom slučaju - one navodno ne zahvaćaju dovoljno duboko i široko kao filozofija, one su, da upotrijebim pojedinim hrvatskim filozofima tako omiljen izraz, "puka« filologija ili "puka« povijest.

To je dijagnoza: raznoliki stilovi i senzibiliteti u filozofiji, onoliko koliko izražavaju različite odnose prema znanostima, u korelaciji su s nesigurnošću koju kao filozofi imamo prema statusu naše discipline u odnosu na znanosti. Ono što sada želim ponuditi neka je vrsta lijeka, a lijek bi, po mome mišljenju, trebao biti u nijekanju da neki problem, pa tako i nesigurnost, uopće postoji. Dopustite mi da to kratko objasnim.

Glavni izvor nesigurnosti, po mome mišljenju, jest uvjerenje da je filozofija danas - namjerno se ograničavam na današnjicu, jer pogled u povijest pružio bi nam vjerojatno drukčiju sliku, a i ono što me zanima jest današnja filozofija - samodostatno, posve autonomno i zasebno područje istraživanja te da se o takvome, zasebnom i samodostatnom području onda pitamo kako se odnosi prema drugim zasebnim i autonomnim područjima. Sukladno tome, pretpostavlja se da su rezultati koji proizlaze iz takva istraživanja također samodostatni i neovisni - da su, drugim riječima, filozofski opisi zbilje neovisni o drugim vrstama opisa te da kao takvi mogu s njima biti oprečni. Oba ta uvjerenja smatram pogrešnima.

Što se tiče prvoga, smatram da sama praksa filozofije pokazuje da je ono pogrešno. Jednostavno, ako radimo bilo koje područje, mi se na ovaj ili onaj način - obilno ili manje obilno, izričito ili prešutno, svjesno ili možda čak nesvjesno - koristimo rezultatima i metodama iz raznih područja znanosti. Upotreba znanosti nije dodatak koji proizlazi iz naslijeđenog, naučenog ili na bilo koji drugi način usvojenog stila ili senzibiliteta filozofiranja. Ono što je specifično za stil i senzibilitet samo je vrsta ili polje znanosti koje rabimo, ali ne i činjenica da ih rabimo. Ako proučavamo metafiziku i ako smo uvjereni da od metafizike možemo očekivati da nam ponudi neke odgovore na krajnje općenito pitanje o tome koja je osnovna struktura zbilje, onda ćemo se u svome metafizičkom istraživanju sigurno na ovaj ili onaj način koristiti rezultatima fizike, druge discipline koja pretendira na to da dade odgovor na pitanje o tome koja je osnovna struktura zbilje. Preciznije govoreći, koristit ćemo se nekim rezultatima fizike - onima koje smatramo relevantnima - ako smo ozbiljni metafizičari, to jest ako uistinu težimo opisati osnovnu strukturu zbilje. Mi možemo smatrati, naravno, da fizika ne može ponuditi neki takav istinit opis. Možemo smatrati da ona ne prodire dovoljno duboko i široko, možda čak da je bez metafizike slijepa. Ako to smatramo, opet se koristimo - ili, točnije, moramo se koristiti - rezultatima fizike. Ako se pritom ne koristimo rezultatima fizike, onda se uopće ne bavimo ozbiljnom metafizikom ili pak naša težnja da damo opis osnovne strukture zbilje nije istinska. Jednako je ako radimo etiku i želimo ponuditi 
nekakav odgovor na pitanja o tome koji je najbolji način života za ljudska bića ili kako karakterizirati čovjekov odnos prema sebi i prema drugima i slično. To su takva pitanja da odgovor na njih ne može a da ne uključi neke uvide iz drugih disciplina, vjerojatno iz područja društvenih znanosti kao što su psihologija ili sociologija, možda iz područja prirodnih znanosti kao što je biologija. Ali to su i takva pitanja da je odgovor na njih možda nemoguć bez uključivanja područja humanističkih znanosti, recimo povijesti ili čak, ako smo takva filozofskog senzibiliteta da smatramo da odgovore možemo naći primjerice kod Platona i Aristotela, klasične filologije. A ne možemo tvrditi da ozbiljno radimo Aristotela ako se ne koristimo rezultatima, a možda i metodama klasične filologije; ako postupamo tako da se ne koristimo klasičnom filologijom, onda možda radimo nešto drugo, ali se naša aktivnost ne može nazvati proučavanjem Aristotela.

Važno mi je jasno naglasiti što točno želim tvrditi. Želim tvrditi da kada danas radimo filozofiju, tada je radimo koristeći se, na ovaj ili onaj način, rezultatima i metodama i prirodnih i društvenih i humanističkih znanosti, te da, ako dovoljno osvijestimo tu činjenicu, pitanje odnosa filozofije prema drugim znanostima neće izazivati nesigurnost, jer su te druge znanosti ionako inkorporirane u filozofsku aktivnost. Kada kažem da su inkorporirane, tada ne mislim na to da su dodane nekoj neovisnoj filozofskoj jezgri koja je sama po sebi lišena znanstvenih pretpostavki i koja čini nekakvu »čistu« filozofiju. Takva jezgra ne postoji; čitava filozofska aktivnost prožeta je, u nekom obliku, znanošću. Činjenice da se u filozofiji koristimo drugim znanostima jesmo svjesni, ali, po mome mišljenju, u pogrešnom obliku - smatramo da su one izvanjski dodatak navodno neovisnome i samodostatnome filozofskom pothvatu te da stoga postoji trajan problem pozicioniranja filozofije u odnosu na druge znanosti. No taj pothvat nije neovisan i samodostatan i, ako pretpostavimo da jednostavno ne postoji »čista«, znanošću neprožeta aktivnost filozofskog istraživanja, onda nema nikakve osnove ni za nesigurnost ni za oholost o kojima sam govorio.

Takvu shvaćanju vjerojatno se, između ostalih, može uputiti i sljedeći prigovor: iako je možda točno - čak i ako to prihvatimo bez temeljitije empirijske provjere - da filozofska aktivnost danas u sebi uključuje druge vrste intelektualne aktivnosti, pitanja koja filozofija postavlja i, osobito, rezultati do kojih dolazi, sasvim su drukčiji od pitanja i rezultata drugih znanosti, pa i onih humanističkih, tako da problem pozicioniranja ostaje. Taj je prigovor zapravo drugo pogrešno uvjerenje koje sam maločas spomenuo. Da bih kratko pokazao zašto je pogrešno, poslužit ću se jednostavnim primjerom.

Osvrnimo se kratko na jedan poznati problem u metafizici. Pretpostavimo da u ruci držim novčanicu od deset kuna. S jedne strane, mogli bismo tvrditi da ono što držim u ruci jest komad materije - komad papira, komad čestica složenih na način papira, kako god hoćete - koji se konvencionalno opisuje, naziva ili vrijedi kao sredstvo plaćanja, novčanica od deset kuna. S druge strane, međutim, mogli bismo tvrditi da ono što držim u ruci nije samo neki 
objekt, komad papira koji se može opisati ili nazvati drukčije, nego još jedan, naime upravo novčanica od deset kuna, to jest da u inventar svijeta moram ubrojiti dva predmeta, i komad papira i novčanicu od deset kuna. Jer, moglo bi se tvrditi, nije stvar u tome da sam ovaj komad papira opisao kao novčanicu od deset kuna i tako je nazvao; stvar je u tome da je novčanica od deset kuna različit predmet nego komad papira. Razlog zašto bih mogao tvrditi da je ona drugi predmet dobro je poznat: novčanica od deset kuna ima drukčija svojstva nego komad papira, odnosno drukčije kriterije ustrajavanja kroz vrijeme, tako da ne može biti numerički identična s komadom papira. Novčanica od deset kuna ima svojstvo da je sredstvo plaćanja, a komad papira to svojstvo nema; kad bih novčanicu od deset kuna razrezao cijelom dužinom, ali ne skroz do kraja, prestala bi biti novčanica od deset kuna - nijedan je trgovac ne bi takvu primio - ali komad papira ostao bi komad papira; novčanica od deset kuna svojevrsno je umjetničko djelo, a komad papira nije itd.

Ponekad se može čuti tvrdnja da je ovakav spor unutar metafizike nerješiv. To bi moglo značiti dvije stvari. Moglo bi značiti da je uistinu nerješiv u tom smislu da su argumenti na objema stranama jednako uvjerljivi i da ne postoji način da, unutar metafizike, jednoj strani damo prednost. No to bi moglo značiti i da je riječ o pseudoproblemu, a ne o stvarnom metafizičkom problemu - da je riječ, primjerice, o verbalnom problemu koji ovisi o tome kako upotrebljavamo riječ kao što je "predmet«. Ja ne mislim da je riječ o verbalnom problemu. Slažem se da je problem unutar metafizike nerješiv ako metafiziku shvatimo kao neovisno i samodostatno područje istraživanja. Uočimo da oba oprečna pristupa novčanici od deset kuna snažno počivaju na izvanmetafizičkim pretpostavkama. Prvi pristup, koji tvrdi da imamo samo jedan predmet, komad materije ili papira ili nakupinu čestica ili čega već, pretpostavlja da je osnovni odgovor na pitanje o osnovnoj strukturi fizike već, barem u najvažnijim crtama, dan - dala ga je fizika, a zadaća metafizičara samo je u tome da riješi preostale konceptualne probleme, kao što je problem (prividnog) sukoba intuicija da u ruci držim i komad papira i novčanicu. Metafizičar, prema takvu pristupu, zapravo radi neku vrstu fizike iz naslonjača, radi nešto što jest doduše metafizika - što sigurno možemo nazvati metafizikom - ali što ne slika neovisnu, navodno filozofsku, sliku svijeta. On stvara sliku čiji su glavni obrisi već dovršeni. Drugi pristup nudi sasvim drukčiju sliku. Prema njemu, u svijetu postoje i novčanice, knjige, umjetničke slike, glazbena djela itd., drugim riječima, postoje predmeti čije je postojanje utvrđeno također na temelju neke druge vrste intelektualne aktivnosti, različite od metafizike. Glavni obrisi te slike također su već dovršeni neovisno o njemu.

Stoga je spor unutar metafizike nerješiv ako se metafizika shvati kao samodostatno područje istraživanja, jer je okvir unutar kojeg metafizičar može stvarati svoju sliku već dan. Ako metafizičar, primjerice, ponudi rješenje koje se temelji na ovom drugom pristupu, ne može tvrditi da je on taj koji je usta- 
novio da je svijet ispunjeniji predmetima nego što to pretpostavlja prvi pristup. Njemu su ti predmeti već ponuđeni, njihovo postojanje ustvrdile su druge vrste intelektualnih aktivnosti, a on ih je samo, zbog svojih specifičnih razloga, uvrstio u opis svijeta za koji smatra da je istinit. Njegovo je rješenje problema rezultat zajedničke aktivnosti više disciplina. Upravo tu činjenicu, tvrdim, treba shvatiti naročito ozbiljno: od početka svog istraživanja pa do samoga konca, predlaganja opisa svijeta, metafizičar je radio s drugima - bili oni fizičari ili povjesničari umjetnosti - i slika svijeta koju nudi nije samo njegova.

Ono što trebamo učiniti samo je snažnije osvijestiti činjenicu da smo kao filozofi uključeni u pothvat koji mora, zbog naravi pitanja koja nastojimo riješiti, biti kolektivan. Tada nam pitanje o pozicioniranju filozofije u odnosu na znanosti više neće biti osobito problematično.

\author{
Filip Grgić* \\ Philosophy as a humanistic discipline ${ }^{* * *}$
}

Summary

The paper discusses how to situate philosophy with respect to the other fields of humanities. It is argued that there is no such thing as an independent or pure philosophical inquiry: the philosophical activity is always informed with insights, results and methods specific for either the sciences or the humanities. Philosophy is necessarily just a part of the collective endeavour to understand the world, which comprises various disciplines. As a consequence, there is no special problem of the relationship between philosophy and science, or between philosophy and humanities.

Key words: humanities, philosophy, science, uncertainty.

(na engl. prev. Filip Grgić)

\footnotetext{
* Filip Grgić, PhD, Full Professor, Institute of Philosophy, Address: Ulica Grada Vukovara 54, HR-10000 Zagreb, Croatia; E-mail: filip@ifzg.hr.

** The exposure at the scientific meeting of the Institute for philosophy with the subject: "The Meaning of the Humanities" took place in the Palace of Matica hrvatska in Zagreb on the $10^{\text {th }}$ of December 2015. The complete exposure will be published in the collection of the conference.
} 